\title{
Characterization of cellular and vascular changes in equine follicles during hCG-induced ovulation
}

\author{
A. Kerban ${ }^{1}$, M. Doré ${ }^{2}$ and J. Sirois ${ }^{1 *}$ \\ ${ }^{1}$ Centre de Recherche en Reproduction Animale and ${ }^{2}$ Département of Pathologie et Microbiologie, Faculté de Médecine Vétérinaire, \\ Université de Montréal, C.P. 5000, Saint-Hyacinthe, Québec, Canada J2S 7C6
}

In contrast to other species, the histology of the equine follicle during ovulation has not been described. Preovulatory follicles were isolated during oestrus at $0,12,24,30,33,36$ and $39 \mathrm{~h}$ ( $n=5-6$ follicles per time point) after an ovulatory dose of hCG to characterize the cellular and vascular changes associated with ovulation in mares. Pieces of follicle wall were formalin-fixed and processed for light microscopy to evaluate the general follicular morphology and quantify selected parameters. Marked changes were observed in the histology of equine follicles in the hours before ovulation. The thickness of the granulosa cell layer doubled between 0 and $39 \mathrm{~h}$ after hCG $(77.8 \pm 4.8$ versus $158.8 \pm 4.8$ $\mu \mathrm{m}$, respectively; $P<0.01$ ). This expansion was caused primarily by a pronounced accumulation of acid mucosubstances between granulosa cells, which was first detected at $12 \mathrm{~h}$ after hCG and peaked at 36-39 h. In contrast, a significant thinning of the theca interna was observed after hCG treatment. Fewer cell layers were present; theca interna cells appeared smaller than before hCG; and the presence of occasional pyknotic cells was noted at 36 and $39 \mathrm{~h}$ after hCG. In addition, the theca layers were invaded by numerous eosinophils. No eosinophils were observed in preovulatory follicles isolated between 0 and $24 \mathrm{~h}$ after hCG, but the number increased to $14.0 \pm 0.8$ and $5.6 \pm 0.3$ eosinophils per field $(x 400)$ in theca interna and theca externa, respectively, $39 \mathrm{~h}$ after hCG treatment $(P<0.01)$. Severe oedema, hyperaemia and haemorrhages, and significant increases in the number of blood vessels in theca interna and externa were observed at 33,36 and $39 \mathrm{~h}$ after hCG. This study provides the first in-depth characterization of the sequential cellular and vascular changes that occur in equine follicles before ovulation.

\section{Introduction}

Ovarian follicular development and ovulation in mares has some unique characteristics compared with that of other large animals. Mares are seasonal polyoestrous animals; the duration of the oestrous cycle is about 20-21 days and is characterized by a relatively long period of oestrus (follicular phase of 5-7 days) (Palmer, 1978; Ginther, 1992; Daels and Hughes, 1993). In most cases, a single cohort or wave of follicles larger than $15 \mathrm{~mm}$ in diameter develops during the oestrous cycle, and the preovulatory follicle is recruited 13-14 days before ovulation (Driancourt and Palmer, 1984; Pierson and Ginther, 1987; Sirois et al., 1989). The maximal size of the preovulatory follicle $(40-45 \mathrm{~mm}$ in diameter) is considerably larger than in other species. Ovulation in mares is not triggered by a typical LH surge. Instead, there is a progressive increase in LH during oestrus, which typically peaks 1 day after ovulation (Whitmore et al., 1973; Stabenfeldt et al., 1975; Alexander and Irvine, 1982), indicating that the ovulatory cascade in horses is initiated when a threshold concentration of gonadotrophin is reached. However, the

${ }^{*}$ Correspondence.

Received 13 November 1998. hormonal and cellular control of oestradiol biosynthesis in the developing equine preovulatory follicle appears to follow the two-cell (theca interna and granulosa cells), twogonadotrophin (LH and FSH) model that is common to other species (Sirois et al., 1991; Almadhidi et al., 1995).

Ovulation in mares can be induced during the follicular phase by the administration of hCG, and the duration of the ovulation, defined as the interval from hCG injection to follicular rupture, is approximately 36-48 h (Duchamp et al., 1987; Watson et al., 1991). In contrast to other species in which follicular rupture occurs over the majority of the ovarian surface, the equine ovulatory process is restricted to a specific region of the ovary, the ovulatory fossa (Stabenfeldt et al., 1975). Some of the biophysical characteristics of equine ovulation have been described using transrectal palpation and ultrasonography. As in other species, rupture does not appear to result from a build-up of pressure within the follicle (Ginther, 1992). The shape and consistency of the equine follicle change as ovulation approaches, from a relatively firm spherical structure to a soft non-spherical (pear-shaped or conical) structure (Pierson and Ginther, 1985). Two patterns of follicular fluid evacuation have been observed after rupture: an abrupt process in which $90 \%$ of the fluid is evacuated during the first $60 \mathrm{~s}$, and a more 
gradual process in which complete evacuation requires 6-7 min (Townson and Ginther, 1987, 1989).

Elucidating the complex cascade of cellular and biochemical events leading to follicular rupture has been the focus of many studies, and the subject of several reviews (Murdoch and Cavender, 1987; Thibault and Levasseur, 1988; Goetz et al., 1991; Tsafriri et al., 1993; Espey and Lipner, 1994). Descriptive histological studies of ovulation have been performed in numerous species, including rabbits (Espey, 1967; Bjersing and Cajander, 1974), various rodents (Byskov, 1969; Parr, 1974; Martin and Talbot, 1987), sheep (Cavender and Murdoch, 1988), cattle (Priedkalns et al., 1968) and humans (Okamura et al., 1980). Whereas differences were noted among species, the collective findings revealed a clear parallel between the gonadotrophin-dependent process and a classic inflammatory reaction (Espey, 1980; Espey and Lipner, 1994). As observed in acute inflammation, hyperaemia, congestion, increased vascular permeability, and the recruitment of white blood cells are present during ovulation. The sequential histology of ovulation has not been characterized in mares, although the microscopic anatomy of the corpus luteum has been described (Harrison, 1946; Van Niekerk et al., 1975; Levine et al., 1979). The objective of this study was to characterize the cellular and vascular changes occurring during the final differentiation of equine preovulatory follicles after a gonadotrophin-induced ovulation to understand better the precise sequence of events leading to follicular rupture in horses.

\section{Materials and Methods}

\section{Materials}

Lutalyse was purchased from UpJohn (Kalamazoo, MI) and hCG was obtained from The Buttler Company (Columbus, $\mathrm{OH}$ ). Rompun was purchased from Haver (Bayvet Division, Shawnee, KS). Torbugesic was obtained from Fort Dodge Laboratories Inc. (Fort Dodge, IA). Dormosedan was purchased from SmithKline Beecham, Animal Health (West Chester, PA). Culture medium was obtained from Gibco Bethesda Research Laboratories Life Technologies Inc. (Gaithersburg, MD).

\section{Animals}

Adult Standardbred and Thoroughbred mares, weighing approximately $375-450 \mathrm{~kg}$, were kept outdoors and fed once a day with hay and concentrates. They were teased once a day with a pony stallion for detection of oestrus, and ovarian follicular development was monitored once a day by transrectal real-time ultrasonography (Sirois et al., 1989). When the preovulatory follicle reached $35 \mathrm{~mm}$ in diameter during oestrus, the animal was injected with 2500 iu hCG i.v. to induce ovulation.

\section{Ovariectomy and isolation of preovulatory follicles}

The ovary bearing the presumptive preovulatory follicle was removed via colpotomy with a chain ecraseur at $0(n=5)$, $12(n=5), 24(n=5), 30(n=5), 33(n=5), 36(n=6)$ and $39 \mathrm{~h}$ $(n=5)$ after hCG, as described by Vaughan (1988) and Sirois et al. (1989). Twenty-seven mares were used for a total of 36 unilateral ovariectomies. Animals used for two consecutive unilateral ovariectomies were allowed a recovery period of more than 40 days and showed at least one normal oestrous cycle before the second surgery. During the procedure, neuroleptanalgesia was induced with a combination of xylazine (Rompun; $0.65 \mathrm{mg} \mathrm{kg}^{-1}$, i.v.), butorphanol (Torbugesic; $0.005 \mathrm{mg} \mathrm{kg}^{-1}$, i.v.) and detomidine (Dormosedan; $0.02 \mathrm{mg}$ $\mathrm{kg}^{-1}$, i.v.) according to Sirois and Dore (1997). The recovered ovary was kept in ice-cold Eagles's minimal essential medium (MEM) supplemented with penicillin $\left(50 \mathrm{U} \mathrm{ml}^{-1}\right)-$ streptomycin (50 $\mathrm{g} \mathrm{ml}^{-1}$; Gibco), L-glutamine $\left(2.0 \mathrm{mmol} \mathrm{l}^{-1}\right.$; Gibco) and non-essential amino acids $\left(0.1 \mathrm{mmol} \mathrm{l}^{-1}\right.$; Gibco). The preovulatory follicle was dissected from the surrounding ovarian tissue with a scalpel, and pieces of the follicle wall were fixed in $10 \%(\mathrm{v} / \mathrm{v})$ neutral buffered formalin. All animal procedures were approved by the institutional animal use and care committee. No complications were observed during the recovery period after surgery, with the exception of one mare that suffered from a severe peritonitis.

\section{Histology}

Formalin-fixed tissues were embedded in paraffin wax and $3 \mu \mathrm{m}$ sections were prepared and stained with haematoxylin-eosin-saffran (HES). Alcian blue ( $\mathrm{pH} 2.5$ ) staining was also performed on selected sections. The morphology of the follicle wall and its cellular constituents were characterized under light microscopy. The following parameters were quantified in the follicle wall: (i) the number of cells and thickness of the granulosa layer; (ii) the number of cells and thickness of the theca interna layer; (iii) the number of blood vessels (capillaries, venules and small veins) in the theca interna and theca externa; and (iv) the number of eosinophils in the theca interna and theca externa. Five representative high-power fields $(\times 400)$ were selected on each section to determine these parameters. In addition, the following parameters were evaluated in a semiquantitative way in the follicle wall: (i) degree of hyperaemia ( 0 = absent, 1 = little, $2=$ moderate, 3 = marked); (ii) degree of oedema ( 0 = absent, 1 = light, 2 = moderate, $3=$ marked); (iii) presence of haemorrhage $(0=$ absent, $1=$ few, $2=$ numerous); and (iv) presence of acid mucosubstances as detected with alcian blue staining ( $\mathrm{pH} 2.5)(0=$ absent, $1=$ little, 2 = moderate, 3 = high, $4=$ very high). Five representative fields $(\times 100)$ were selected on each section to determine these parameters.

\section{Statistical analyses}

The effect of time after hCG treatment on the number of cells and thickness of the granulosa and theca layers, and on the number of blood vessels and eosinophils in the theca layers was tested by one-way analysis of variance (ANOVA). When ANOVAs indicated significant differences $(P<0.05)$, 

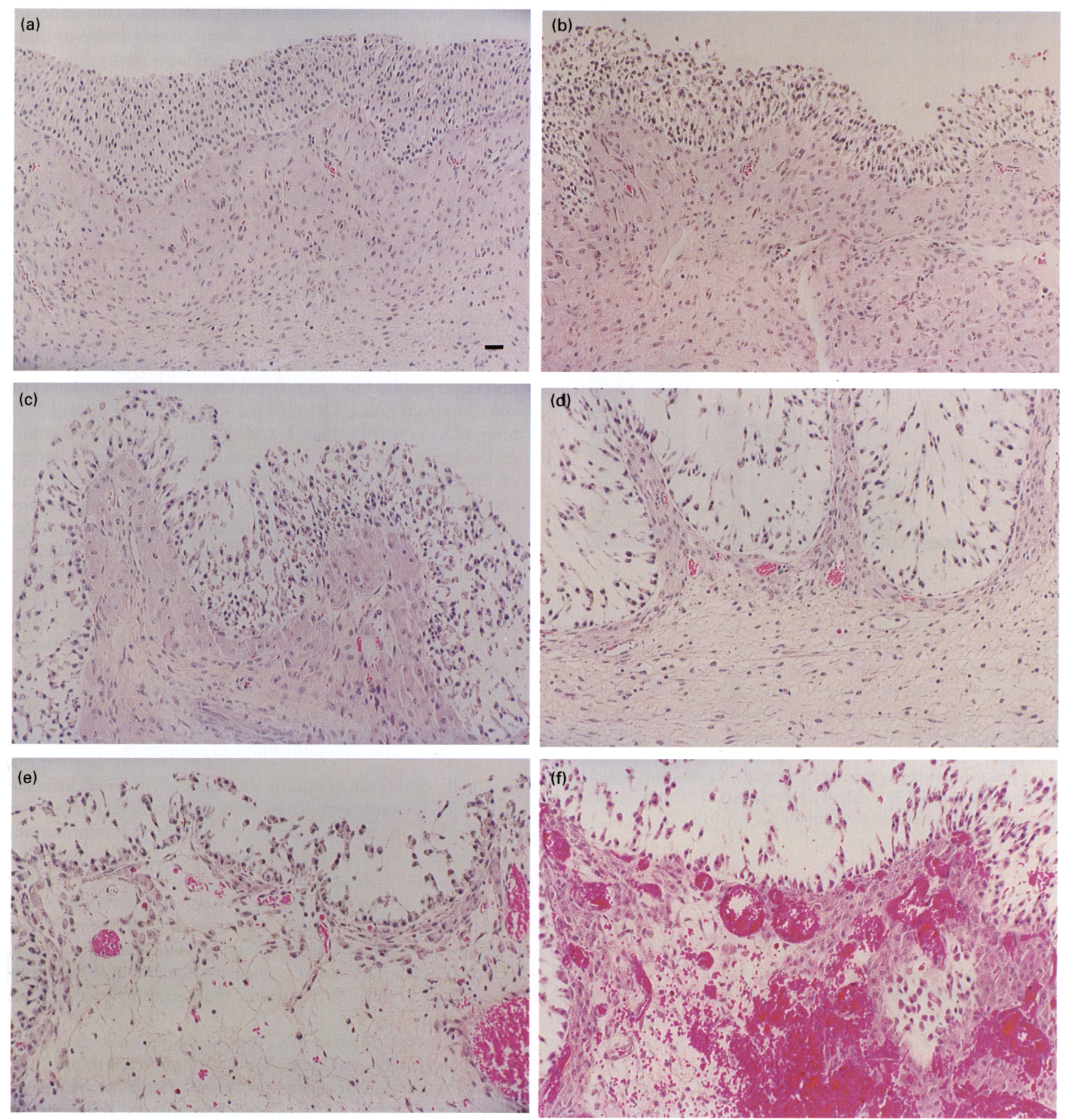

Fig. 1. Histology of equine preovulatory follicles during hCG-induced ovulation. Sections of follicle walls were prepared from equine preovulatory follicles isolated during oestrus at (a) 0 , (b) 12, (c) 24, (d) 30 , (e) 36 and (f) $39 \mathrm{~h}$ after hCG treatment. Note the loosening of the granulosa cell layer $(c-f)$, thinning of the theca interna $(d-f)$, developing oedema $(d-f)$ and progressive vascular changes $(e, f)$. Scale bar represents $25 \mu \mathrm{m}$.

multiple comparisons of means were made using the Dunett's test to compare different time points after hCG with $0 \mathrm{~h}$. The effect of time after hCG treatment on the degree of hyperaemia and oedema, and on the presence of haemorrhage and acid mucosubstances was tested by
Kruskal-Wallis one-way ANOVA by ranks, followed by Wilcoxon rank sum tests to compare different times after hCG with $0 \mathrm{~h}$. Analyses were performed with JMP software (Statistical Analysis System Institutes, Cary, NC). Data are presented as mean $\pm \operatorname{SEM}(n=5-6$ follicles per time point). 

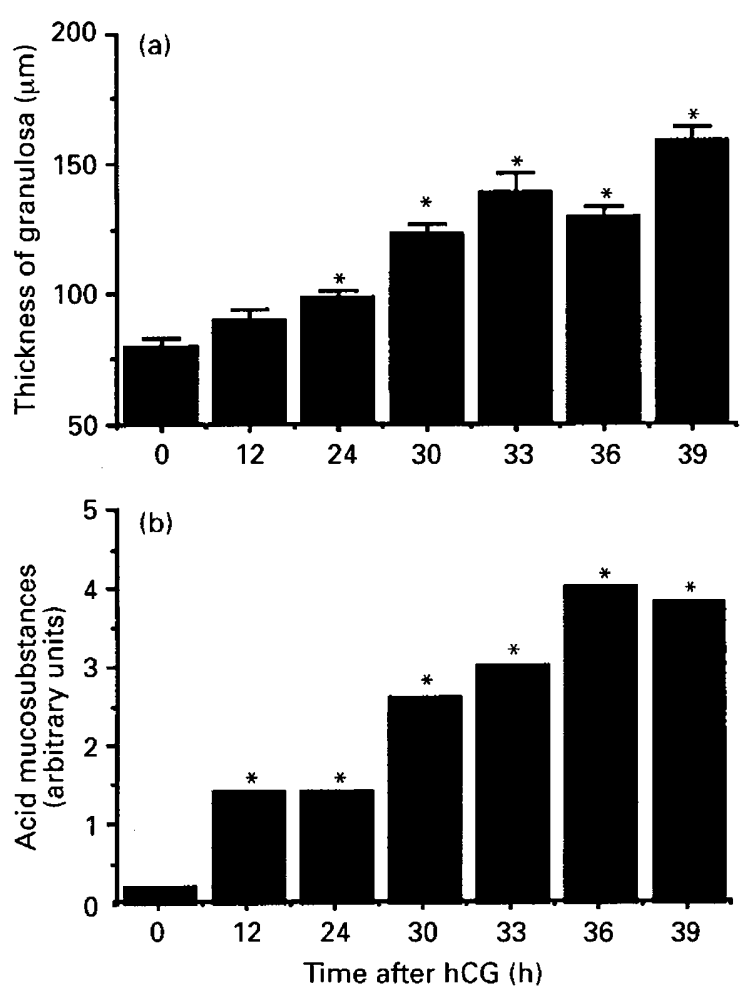

Fig. 2. Changes in the granulosa cell layer of equine preovulatory follicles after hCG treatment. (a) Effect of hCG on the thickness of the granulosa cell layer. Sections of follicle walls of equine preovulatory follicles were isolated between 0 and $39 \mathrm{~h}$ after hCG, and the thickness of the granulosa cell layer was measured. (b) Time- and gonadotrophin-dependent accumulation of acid mucosubstances. The relative amount of acid mucosubstances in the granulosa cell layer was estimated using an arbitrary scale. Results are presented as mean $\pm \operatorname{SEM}(n=5-6$ follicles per time point). Bars with an asterisk are significantly different from time $0 \mathrm{~h}(P<0.01)$.

\section{Results}

\section{Macroscopic characteristics of equine preovulatory follicles}

Thirty-six equine preovulatory follicles were isolated during oestrus between 0 and $39 \mathrm{~h}$ after hCG, including five follicles at $0,12,24,30,33$ and $39 \mathrm{~h}$, and six follicles at $36 \mathrm{~h}$ after hCG treatment. The overall mean follicle diameter was $39.4 \pm 0.5 \mathrm{~mm}$, and no significant difference was observed across time points after hCG $(P>0.05)$. All preovulatory follicles recovered between 0 and $36 \mathrm{~h}$ were intact, whereas two of the five follicles obtained $39 \mathrm{~h}$ after hCG ruptured accidentally during the procedure. Follicles isolated at $39 \mathrm{~h}$ after hCG appeared easily deformable at the ultrasound examination before the surgery and were very soft upon palpation, indicating imminent ovulation. After follicles were dissected and opened with scissors, a clear circular haemorrhagic area of approximately $1.0-1.5 \mathrm{~cm}$ in diameter located towards the ovulatory fossa was observed in the wall of four of the five follicles obtained $39 \mathrm{~h}$ after hCG. Only one follicle isolated at $36 \mathrm{~h}$ contained a similar haemorrhagic region, whereas none was observed in follicles at earlier time points. A mucoid substance coating the luminal side of the follicle was observed after hCG treatment. This mucoid substance became more apparent macroscopically at $30 \mathrm{~h}$ after hCG, and made the granulosa cell layer sticky.

\section{Microscopic gonadotrophin-induced changes in the granulosa cell layer}

The administration of hCG induced marked microscopic changes in the granulosa cell layer (Fig. 1). Before hCG treatment $(0 \mathrm{~h})$, the granulosa cell layer was composed of four to nine compact layers of small elongated cells. These cells contained a small dark-staining nucleus that was often located in a basal position. Mitotic figures were occasionally observed (0-2 mitoses per field; $\times 400)$. Gonadotrophin treatment caused a marked loosening of the granulosa cell layer that resulted in a significant increase in the thickness of the layer from $77.8 \pm 4.8$ to $158.8 \pm 4.8 \mu \mathrm{m}$ between 0 and $39 \mathrm{~h}$ after hCG $(P<0.01$; Figs 1 and 2$)$. The marked loosening of the granulosa cell layer was the result of accumulation of mucoid material between the cells. Alcian blue staining revealed that this material was composed of acid mucosubstances (Fig. 3a,b). The accumulation was progressive, but was greatest at 36 and $39 \mathrm{~h}$ after hCG $(P<0.01$; Fig. $2 \mathrm{~b})$. No mitotic figures were observed in the granulosa cell layer after hCG treatment. The mean number of layers of granulosa cells increased between 0 and $24 \mathrm{~h}$ after hCG (5.5 \pm 0.2 and $6.4 \pm 0.2$ cells, respectively; $P<0.01$ ), but did not increase thereafter.

\section{Microscopic gonadotrophin-induced changes in theca layers}

The theca interna of equine preovulatory follicles isolated before hCG treatment $(0 \mathrm{~h})$ was relatively thick $(85.5 \pm$ $4.5 \mu \mathrm{m}$; Fig. 4), and composed of plump polyhedral cells containing a light-staining nucleus (Fig. 1). The layer was well vascularized, containing numerous vessels $(6.6 \pm 0.5$ vessels per field; $\times 400$; Fig. 5). The theca externa was less vascularized $(3.5 \pm 0.4$ vessels per field; $\times 400$; Fig. 5$)$ and composed of small fibroblasts. The boundary between theca interna and theca externa was easily detectable at this time point $(0 \mathrm{~h}$ after $\mathrm{hCG})$, because of marked differences in cell morphology.

The administration of hCG caused marked changes in the morphology of theca layers (Fig. 1). A significant thinning of the theca interna layer was observed after hCG treatment (Fig. 4). Fewer cell layers were present, theca interna cells appeared smaller than before hCG, and the presence of occasional pyknotic cells was noted at 36 and $39 \mathrm{~h}$ after hCG. In addition, there was marked infiltration of theca layers by eosinophils. Equine eosinophilic leucocytes were easily recognizable by the very large and tightly packed cytoplasmic granules that give the cells a raspberry-like appearance (Jain, 1986). No eosinophils were observed in theca interna and theca externa of preovulatory follicles isolated between 0 and $24 \mathrm{~h}$ after hCG, but a rapid and significant increase in numbers occurred thereafter (Figs 3c,d and 6). The number of eosinophils per field $(\times 400)$ in the theca interna increased from $0.65 \pm 0.06$ to $14.0 \pm 1.5$ between 

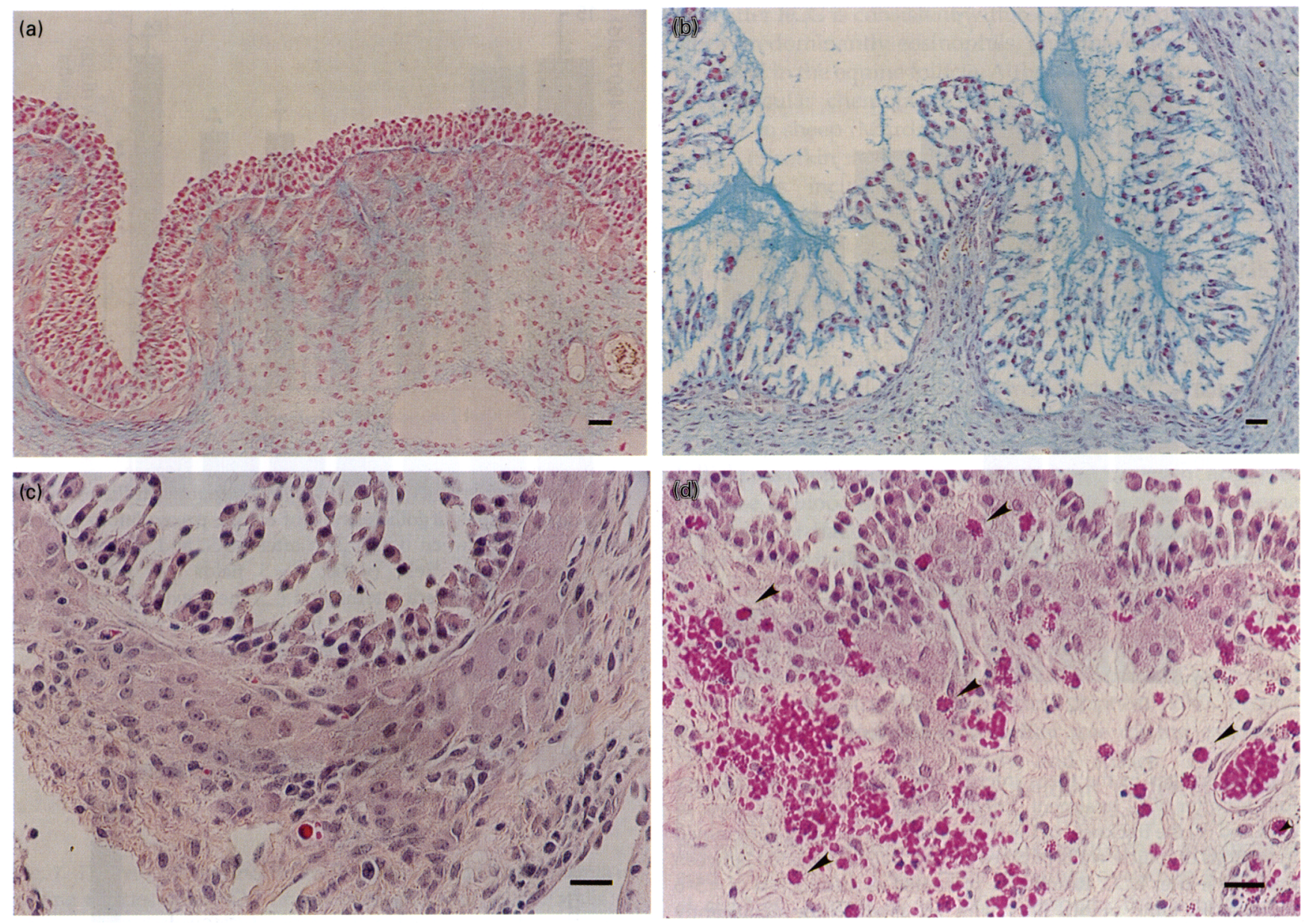

Fig. 3. Accumulation of acid mucosubstances in the granulosa cell layer $(a, b)$ and the infiltration of eosinophils in theca layers (c,d) in equine follicles during hCG-induced ovulation. Sections of follicle walls were prepared from equine preovulatory follicles isolated at (a) 0 , (c) 30 and (b,d) $39 \mathrm{~h}$ after hCG, and stained with haematoxylin-eosin-saffran $(\mathrm{a}, \mathrm{b})$ or alcian blue, $\mathrm{pH} 2.5$ (c,d). Arrowheads (d) indicate five of $>40$ eosinophils that are present in this field. Scale bars represent $25 \mu \mathrm{m}$.

30 and $39 \mathrm{~h}$ after hCG, respectively $(P<0.05)$. Numerous eosinophils were observed migrating along the endothelium of small vessels and into the extravascular compartment (Fig. $3 \mathrm{c}, \mathrm{d})$.

Marked vascular changes were observed in theca layers after hCG treatment (Fig. 1). These changes included significant increases in the degree of oedema, haemorrhages and hyperaemia, which were maximal at 36 and $39 \mathrm{~h}$ after hCG (Fig. 7). The number of blood vessels (per field; $\times 400$ ) in the theca interna and theca externa was significantly increased at 33,36 and $39 \mathrm{~h}$ after hCG, respectively $(P<0.01 ;$ Fig. 5$)$.

\section{Discussion}

This study is the first to provide an in-depth characterization of the sequential cellular and vascular changes that occur in equine follicles before ovulation. In contrast to detailed reports in other species, histological investigations of ovarian structures in mares have been limited and have focused primarily on the corpus luteum (Harrison, 1946; Van Niekerk et al., 1975; Levine et al., 1979). In this study, changes in the microscopic anatomy of the equine follicle were characterized using 36 presumptive preovulatory follicles identified by ultrasonography and isolated during oestrus at specific times after the administration of an ovulatory dose of hCG. The induction of ovulation was associated with extensive remodelling of the granulosa cell layer. The marked expansion of the layer was, to an extent, reminiscent of a process thought to be limited to the cumulus-oocyte complex (Salustri et al., 1996). Although a loosening of granulosa cells just before ovulation has been reported in other species (Priedkalns et al., 1968; Parr, 1974; Cherney et al., 1975), the degree of expansion observed in mares appears unique. The precise nature of the mucosubstances secreted during cellular expansion remains to be determined, but are likely to include members of the glycosaminoglycan family (hyaluronan, heparan sulfate or dermatan sulfate) as observed in other species (Grimek et al., 1984; Bellin and Ax, 1987; Jackson et al., 1991; Chen et al., 1993; Boushehri et al., 1996; Tirone et al., 1997). The remodelling of the granulosa layer is not restricted to hCG treatment since it has also been observed in equine preovulatory follicles isolated during late oestrus (Ginther, 1992; J. Sirois, unpublished). A consequence 

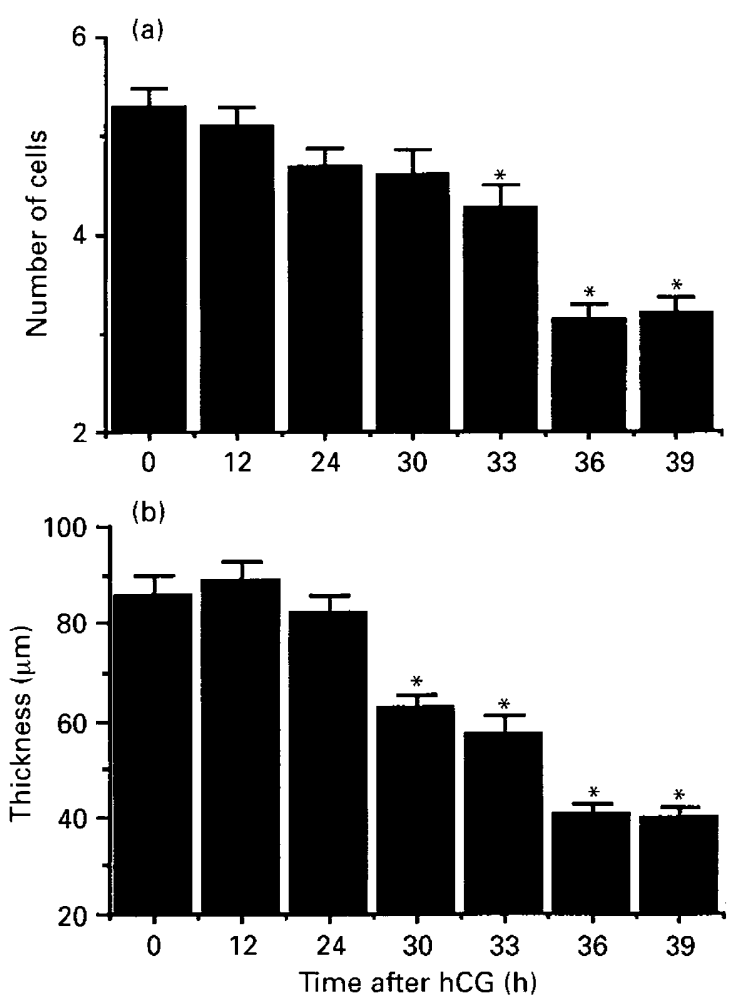

Fig. 4. Changes in the theca interna layer of equine preovulatory follicles after hCG treatment. Effects of hCG on (a) the number of cells and (b) the thickness of the theca interna layer were determined in sections of follicle walls of preovulatory follicles isolated between 0 and $39 \mathrm{~h}$ after hCG. Results are presented as mean \pm SEM ( $n=5-6$ follicles per time point). Bars with an asterisk are significantly different from time $0 \mathrm{~h}(P<0.01)$.

of the large amount of mucosubstances produced is the progressive entrapment of granulosa cells. This entrapment makes isolation of equine cells for in vitro studies particularly tedious during the late stages of ovulation, and repeated centrifugations and washes are required.

In a study that focused primarily on the histology of the developing equine corpus luteum, Van Niekerk et al. (1975) reported that theca interna cells degenerate at ovulation in mares and, therefore, in contrast to other species, do not contribute to the luteal tissue. The results of the present study are consistent with this finding, as a marked thinning of the theca interna and occasional cell pyknosis were observed after hCG treatment. These changes were observed primarily at the end of ovulation, and probably relate to the requirement for adequate thecal androgen production during the follicular phase to maintain follicular oestradiol biosynthesis. A potential biochemical consequence of thecal degeneration was indicated by the marked decrease in transcripts encoding the steroidogenic acute regulatory protein (StAR) in these cells at 36 and $39 \mathrm{~h}$ after hCG (Kerban et al., 1999). However, the putative degeneration of the theca interna in mares remains obscure, since it has not been reported in other species. Future investigations should concentrate on determining the nature of the process

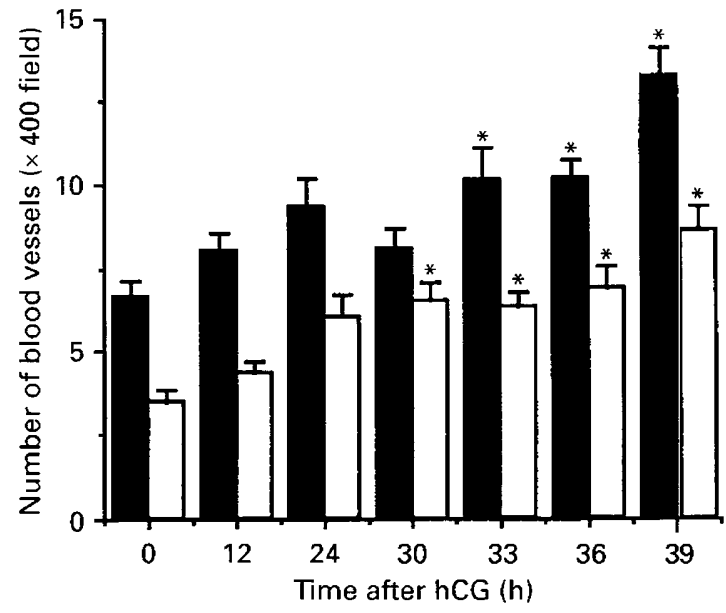

Fig. 5. Number of thecal blood vessels in equine follicles before ovulation. Sections of follicle walls of equine preovulatory follicles were isolated between 0 and $39 \mathrm{~h}$ after hCG, and the number of blood vessels per field $(\times 400 ; n=5$ fields per follicle) was determined in $(\square)$ theca interna and $(\square)$ theca externa. Results are presented as mean \pm SEM ( $n=5-6$ follicles per time point). Bars with an asterisk are significantly different from time $0 \mathrm{~h}(P<0.01)$.

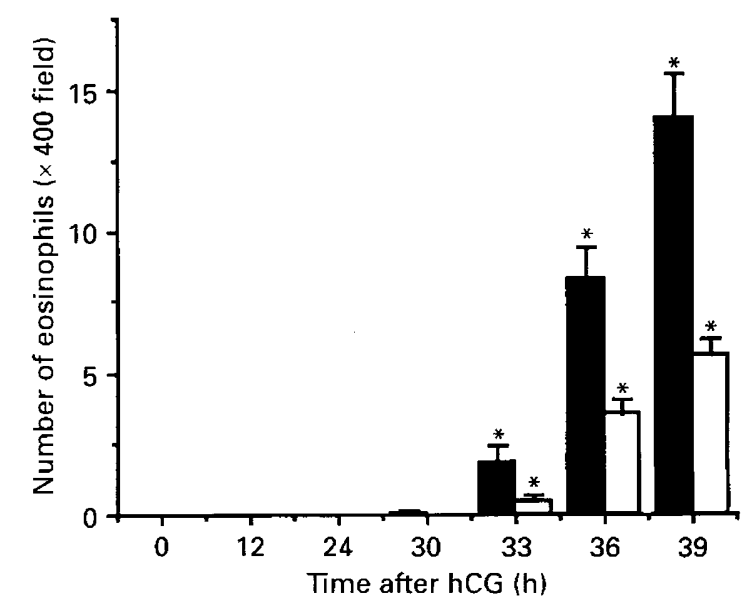

Fig. 6. Time course of eosinophil infiltration into theca interna and theca externa of equine follicles after hCG treatment. Sections of follicle walls of equine preovulatory follicles were isolated between 0 and $39 \mathrm{~h}$ after $\mathrm{hCG}$, and the number of eosinophils per field $(\times 400)$ was determined in $(\square)$ theca interna and $(\square)$ theca externa. Results are presented as mean $\pm \operatorname{SEM}(n=5-6$ follicles per time point). Bars with an asterisk are significantly different from time $0 \mathrm{~h}$ $(P<0.01)$.

involved (apoptosis versus necrosis), as well as the cellular and molecular mechanisms responsible for cell death.

This is the first study to report the extensive migration of eosinophilic leucocytes into the equine follicle wall during ovulation. The attraction of white blood cells from the circulation into theca layers of preovulatory follicles has been reported in other species (Cavender and Murdoch, 1988; Standaert et al., 1991; Gerdes et al., 1992; Brannstrom et al., 1993), supporting their role in the inflammatory-like Downloaded from Bioscientifica.com at 04/26/2023 10:15:40AM 

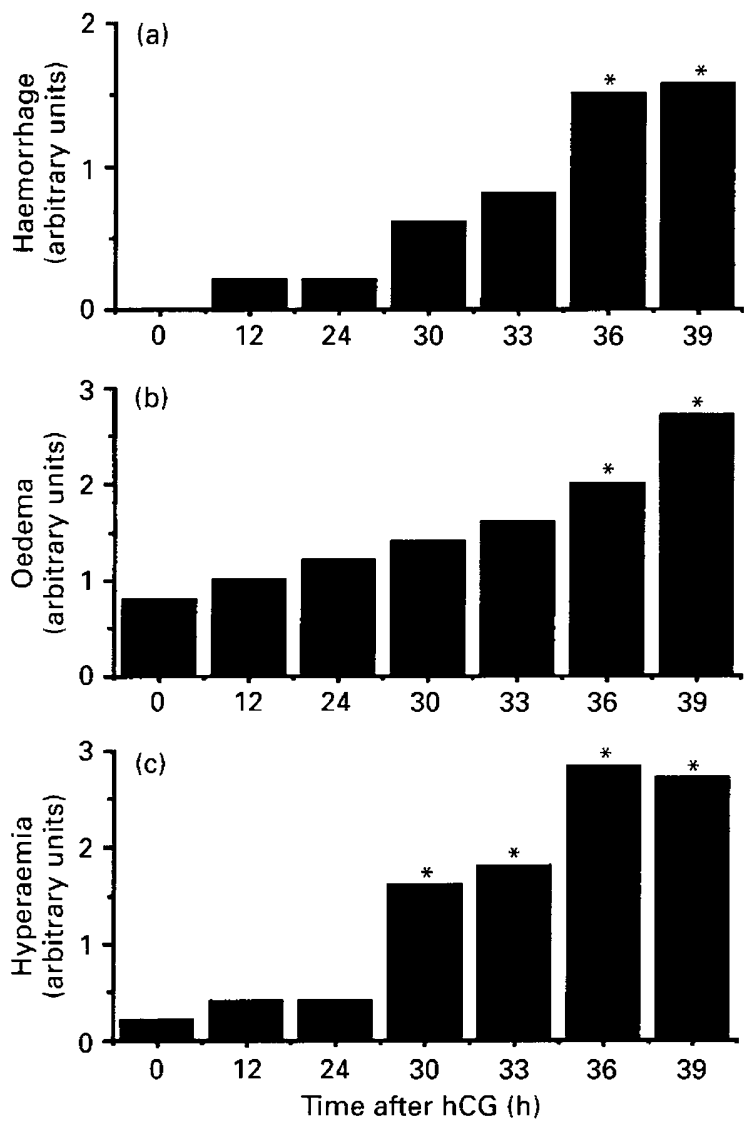

Fig. 7. Degree of (a) haemorrhage, (b) oedema and (c) hyperaemia in equine follicles after hCG treatment. Sections of follicle walls of equine preovulatory follicles were isolated between 0 and $39 \mathrm{~h}$ after hCG, and the degree of haemorrhage, oedema and hyperaemia were determined using an arbitrary scale. Results are presented as mean of 5-6 follicles per time point. Bars with an asterisk are significantly different from time $0 \mathrm{~h}(P<0.01)$.

response in the ovary at ovulation. There appear to be species-related differences in the leucocyte subtype attracted into the preovulatory follicle; eosinophils are predominant in equine (this study) and pig follicles (Standaert et al., 1991) and neutrophils are the principal leucocyte detected in rat (Brannstrom et al., 1993) and rabbit follicles (Gerdes et al., 1992). Eosinophils were first detected at $33 \mathrm{~h}$ after hCG in equine follicles, which coincides precisely with the gonadotrophin-dependent induction of prostaglandin synthesis in granulosa cells before ovulation (Watson and Sertich, 1991; Sirois and Dore, 1997). However, a causal relationship between prostaglandin synthesis and leucocyte migration is not supported by studies in other species (Espey et al., 1981; Chun et al., 1993).

Leucocyte chemoattractant activities have been detected in fluid and cellular extracts of bovine (Sirotkin and Luck, 1995), equine (Watson et al., 1991), human (Seow et al., 1988) and ovine follicles (Murdoch and McCormick, 1989). The finding of Watson et al. (1991) that there was no significant difference in the neutrophil chemotactic activity of fluid aspirated from equine preovulatory follicles between 0 and
$36 \mathrm{~h}$ after hCG is consistent with results of the present study, since predominantly eosinophils, and not neutrophils, were attracted in the equine follicle. Although the precise nature of the follicular chemotactic signal has not been identified, studies in sheep (Murdoch and McCormick, 1989, 1993) and cattle (Sirotkin and Luck, 1995) indicate that potential candidates include collagen-like peptides, collagenase, ascorbic acid and calcium ions. However, the precise functions of the massive follicular eosinophilia in mares during ovulation remain uncertain. Depletion of circulatory eosinophils in sheep using prednisolone prevented the characteristic eosinophilia in preovulatory follicles, but did not affect ovulation (Murdoch and Steadman, 1991). Similarly, severe depletion of circulatory leucocytes in rats tid not prevent ovulation (Chun et al., 1993).

Marked vascular changes were observed in the equine follicle as ovulation approached, including an apparent increase in blood supply, hyperaemia, vasodilation, oedema and haemorrhages. These changes have been described in other species and helped to establish a clear parallel between the ovulation and a classic inflammatory reaction (Espey, 1980). However, attempts to identify the follicular mediators responsible for the gonadotrophin-induced vascular response have not produced consistent results (Goetz et al., 1991; Tsafriri et al., 1993; Espey and Lipner, 1994). Prostaglandins are thought to play a key role during ovulation (Murdoch et al., 1993; Priddy and Killick, 1993). The observation that female mice deficient for prostaglandin G/H synthase 2 (PGHS-2), the first rate-limiting enzyme in the biosynthetic pathway of prostaglandins from arachidonic acid (Herschman, 1996), have impaired ovulation (Dinchuk et al., 1995; Lim $\mathrm{H}$ et al., 1997) supports this proposal. In equine preovulatory follicles, a selective induction of PGHS-2 in granulosa cells beginning $30 \mathrm{~h}$ after hCG treatment is responsible for the marked increase in follicular prostaglandin synthesis before ovulation (Watson and Sertich, 1991; Sirois and Dore, 1997; Boerboom and Sirois, 1998). Increased concentrations of prostaglandins are likely to be involved in the vascular response observed in the present study, as well as in the proteolytic and collagenolytic activities needed for follicular rupture (Tsafriri et al., 1993).

In summary, this study is the first to characterize the cellular and vascular changes that occur in equine follicles during ovulation. Owing to the variable duration of the follicular phase in mares and the absence of a discrete LH preovulatory surge (Whitmore et al., 1973; Stabenfeldt et al., 1975; Alexander and Irvine 1982), exogenous gonadotrophin (hCG) was used to induce ovulation and enable the chronology of the follicular response to be determined. The main findings regarding ovulation in mares included a marked expansion of the granulosa cell layer, a putative degeneration of theca interna cells, and a pronounced follicular eosinophilia. Future studies are required to determine the cellular and molecular basis for these gonadotrophin-induced changes in equine follicles before ovulation.

This study was supported by Natural Sciences and Engineering Research Council of Canada Grant OGP0171135. A. Kerban was supported by a fellowship from Al-Fateh University. 


\section{References}

Alexander S and Irvine CHG (1982) Radioimmunoassay and in vitro bioassay of serum LH throughout the equine oestrous cycle Journal of Reproduction and Fertility Supplement 32 253-260

Almadhidi J, Seralini GE, Fresnel J, Silberzahn P and Gaillard JC (1995) Immunohistochemical localization of cytochrome $\mathrm{P} 450$ aromatase in equine gonads Journal of Histochemistry and Cytochemistry 43 571-577

Bellin ME and Ax RL (1987) Chemical characteristics of follicular glycosaminoglycans Advances in Experimental Medicine and Biology 219 731-735

Bjersing L and Cajander S (1974) Ovulation and the mechanism of follicle rupture. I. Light microscopic changes in rabbit ovarian follicles prior to induced ovulation Cell Tissue Research 149 287-300

Boerboom D and Sirois J (1998) Molecular characterization of equine prostaglandin $\mathrm{G} / \mathrm{H}$ synthase- 2 and regulation of its messenger ribonucleic acid in preovulatory follicles Endocrinology 139 1662-1670

Boushehri I, Yadav MC and Meur SK (1996) Characteristics of proteoglycans of buffalo ovarian follicular fluid during maturation of follicles Indian Journal of Biochemistry and Biophysics 33 213-217

Brannstrom M, Mayrhofer G and Robertson SA (1993) Localization of leukocyte subsets in the rat ovary during the periovulatory period Biology of Reproduction 48 277-286

Byskov AG (1969) Ultrastructural studies on the preovulatory follicle in the mouse ovary Zeitchrift Fur Zellforschung Und Mikroskopische Anatomie 100 285-299

Cavender JL and Murdoch WJ (1988) Morphological studies of the microcirculatory system of periovulatory ovine follicles Biology of Reproduction 39 989-997

Chen L, Russell PT and Larsen WJ (1993) Functional significance of cumulus expansion in the mouse: roles for the preovulatory synthesis of hyaluronic acid within the cumulus mass Molecular Reproduction and Development 34 87-93

Cherney DD, Didio L and Motta P (1975) The development of rabbit ovarian follicles following copulation Fertility and Sterility 26 257-270

Chun SY, Daphna-Iken D, Calman D and Tsafriri A (1993) Severe leukocyte depletion does not affect follicular rupture in the rat Biology of Reproduction 48 905-909

Daels PF and Hughes JP (1993) The normal estrous cycle. In Equine Reproduction pp 121-132 Eds AO McKinnon and JL Voss. Lea \& Febiger, Philadelphia

Dinchuk JE, Car BD, Focht KJ et al. (1995) Renal abnormalities and an altered inflammatory response in mice lacking cyclooxygenase II Nature 378 406-409

Driancourt MA and Palmer E (1984) Time of ovarian follicular recruitment in cyclic pony mares Theriogenology $21591-600$

Duchamp G, Bour B, Combarnous Y and Palmer E (1987) Alternative solutions to hCG induction of ovulation in the mare lournal of Reproduction and Fertility Supplement 35 221-228

Espey LL (1967) Ultrastructure of the apex of the rabbit Graafian follicle during the ovulatory process Endocrinology $81267-276$

Espey LL (1980) Ovulation as an inflammatory reaction - a hypothesis Biology of Reproduction 22 73-106

Espey LL, Coons PJ, Marsh JM and LeMaire WJ (1981) Effect of indomethacin on preovulatory changes in the ultrastructure of the rabbit Graafian follicle Endocrinology 108 1040-1048

Espey LL and Lipner H (1994) Ovulation. In The Physiology of Reproduction pP 725-780 Eds E Knobil and JD Neill. Raven Press, New York

Gerdes U, Gravels M, Bergh A and Cajander S (1992) Localized increases in ovarian vascular permeability and leucocyte accumulation after ovulation in rabbits Journal of Reproduction and Fertility 95 539-550

Ginther OJ (1992) Characteristics of the ovulatory season. In Reproductive Biology of the Mare pp 173-235. Equiservices, Wisconsin

Goetz FW, Berndtson AK and Ranjan M (1991) Ovulation: mediators at the ovarian level. In Vertebrate Endocrinology: Fundamentals and Biomedical Implications pp 127-203 Eds PKT Pang, MP Schreibman and R Jones. Academic Press, New York

Grimek HJ, Bellin ME and Ax RL (1984) Characteristics of proteoglycans isolated from small and large bovine ovarian follicles Biology of Reproduction 30 397-409

Harrison RJ (1946) The early development of the corpus luteum in the mare Journal of Anatomy 8 160-166

Herschman HR (1996) Review: prostaglandin synthase-2 Biochemica et Biophysica Acta 1299 125-140
Jackson JA, Friberg AC and Bahr JM (1991) Preovulatory changes in glycosaminoglycans and collagen content in the stigma region of the follicle of the domestic hen Biology of Reproduction 45 301-307

Jain NC (1986) The horse: normal hematology with comments on response to disease. In Schalm's Veterinary Hematology pp 140-177. Lea \& Febiger, Philadelphia

Kerban A, Boerboom D and Sirois J (1999) Human chorionic gonadotropin induces an inverse regulation of steroidogenic acute regulatory protein messenger ribonucleic acid in theca interna and granulosa cells of equine preovulatory follicles Endocrinology $140667-674$

Levine $H_{r}$ Wight $T$ and Squires $E$ (1979) Ultrastructure of the corpus luteum of the cycling mare Biology of Reproduction 20 492-504

Lim H, Paria BC, Das SK, Dinchuc JE, Langenbach R, Trzaskos JM and Dey SK (1997) Multiple female reproductive failures in cyclooxygenase 2deficient mice Cell 91 197-208

Martin GG and Talbot P (1987) Formation of the rupture site in preovulatory hamster follicles: morphological and morphometric analysis of thinning of the granulosa and thecal layers Gamete Research 17 303-320

Murdoch WJ and Cavender JL (1987) Mechanisms of ovulation Advances in Contraceptive Delivery Systems 3353-366

Murdoch WJ and McCormick RJ (1989) Production of low molecular weight chemoattractants for leukocytes by periovulatory ovine follicles Biology of Reproduction $4186-90$

Murdoch WJ, Hansen TR and McPherson LA (1993) A review - role of eicosanoids in vertebrate ovulation Prostaglandins 46 85-115

Murdoch WJ and McCormick RJ (1993) Mechanisms and physiological implications of leucocyte chemoattraction into periovulatory ovine follicles Journal of Reproduction and Fertility $97375-380$

Murdoch WJ and Steadman LE (1991) Investigations concerning the relationship of ovarian eosinophilia to ovulation and luteal function in the sheep American Journal of Reproductive Immunology 25 81-87

Okamura H, Takenaka A, Yajima Y and Nishimura T (1980) Ovulatory changes in the wall at the apex of the human Graafian follicle Journal of Reproduction and Fertility 58 153-155

Palmer E (1978) Control of the oestrous cycle of the mare Journal of Reproduction and Fertility 54 495-505

Parr EL (1974) Histological examination of the rat ovarian follicle wall prior to ovulation Biology of Reproduction 11 483-503

Pierson RA and Ginther Of (1985) Ultrasonic evaluation of the preovulatory follicle in the mare Theriogenology 24 359-368

Pierson RA and Ginther OJ (1987) Follicular population dynamics during the estrous cycle of the mare Animal Reproduction Science 14 219-231

Priddy AR and Killick SR (1993) Eicosanoids and ovulation Prostaglandins Leukotrienes and Essential Fatty Acids 49 827-831

Priedkalns J, Weber AF and Zemjanis R (1968) Qualitative and quantitative morphological studies of the cells of the membrane granulosa, theca interna and corpus luteum of the bovine ovary Zeitchrift Fur Zellforschung Und Mikroskopische Anatomie 85 501-520

Salustri A, Camaioni A and D'Alessandris C (1996) Paracrine and endocrine regulation of cumulus expansion Zygote 4 313-315

Seow WK, Thong YH, Waters MJ, Walters $\mathbf{M}$ and Cummins JM (1988) Isolation of a chemotactic protein for neutrophils from human ovarian follicular fluid International Archives of Allergy and Applied Immunology 86 $331-336$

Sirois J, Ball BA and Fortune JE (1989) Patterns of growth and regression of ovarian follicles during the oestrous cycle and after hemiovariectomy in mares Equine Veterinary Journal Supplement 8 43-48

Sirois J, Kimmich TL and Fortune JE (1991) Steroidogenesis by equine preovulatory follicles: relative roles of theca interna and granulosa cells Endocrinology 128 1159-1166

Sirois J and Dore $\mathbf{M}$ (1997) The late induction of prostaglandin G/H synthase2 in equine preovulatory follicles supports its role as a determinant of the ovulatory process Endocrinology 138 4427-4434

Sirotkin AV and Luck MR (1995) Potential leukocyte attractants in the bovine peri-ovulatory ovary Reproduction Nutrition Development 35 675-683

Stabenfeldt GH, Hughes JP, Evans JW and Geschwind II (1975) Unique aspects of the reproductive cycle of the mare Journal of Reproduction and Fertility Supplement 23 155-160

Standaert FE, Zamora CS and Chew BP (1991) Quantitative and qualitative changes in blood leukocytes in the porcine ovary American Journal of Reproductive Immunology 25 163-168

Thibault C and Levasseur MC (1988) Ovulation Human Reproduction 3 $513-523$ 
Townson DH and Ginther OJ (1987) Duration and pattern of follicular evacuation during ovulation in the mare Animal Reproduction Science 15 $131-138$

Townson DH and Ginther OJ (1989) Ultrasonic characterization of follicular evacuation during ovulation and fate of the discharged follicular fluid Animal Reproduction Science 20 131-141

Tirone E, D'Alessandris C, Hascall VC, Siracusa C and Salustri A (1997) Hyaluronan synthesis by mouse cumulus cells is regulated by interactions between follicle-stimulating hormone (or epidermal growth factor) and a soluble oocyte factor (or transforming growth factor beta 1) Journal of Biological Chemistry 272 4787-4794

Tsafriri A, Chun SY and Reich R (1993) Follicular rupture and ovulation. In The Ovary pp 227-244 Eds EY Adashi and PCK Leung. Raven Press, New York

Van Niekerk CH, Morgenthal JC and Gerneke WH (1975) Relationship between the morphology of, and progesterone production by, the corpus luteum of the mare fournal of Reproduction and Fertility Supplement 23 $171-175$

Vaughan JT (1988) The female genital system. In Textbook of Large Animal Surgery pp 581-583 Ed. FW Oehme. Wiliams and Wilkins, Baltimore

Watson ED and Sertich PL (1991) Concentrations of arachidonic metabolites, steroids and histamine in preovulatory horse follicles after administration of human chorionic gonadotropin and the effect of intrafollicular injection of indomethacin Journal of Endocrinology 129 131-139

Watson ED, Sertich PL and Zanecosky HG (1991) Detection of chemotactic factors in preovulatory follicular fluid from mares American Journal of Veterinary Research 52 1412-1415

Whitmore HL, Wentworth BC and Ginther OJ (1973) Circulating concentrations of luteinizing hormone during estrous cycle of mares as determined by radioimmunoassay American Journal of Veterinary Research 34 $631-636$ 